\title{
Kernos
}

Revue internationale et pluridisciplinaire de religion grecque antique

18 | 2005

Varia

\section{Actes de colloques, ouvrages collectifs et mélanges}

\section{(2) OpenEdition}

\section{Journals}

Édition électronique

URL : http://journals.openedition.org/kernos/1848

DOI : $10.4000 /$ kernos.1848

ISSN : 2034-7871

\section{Éditeur}

Centre international d'étude de la religion grecque antique

Édition imprimée

Date de publication : 1 janvier 2005

Pagination : 560-569

ISSN : 0776-3824

\section{Référence électronique}

"Actes de colloques, ouvrages collectifs et mélanges », Kernos [En ligne], 18| 2005, mis en ligne le 04 juillet 2011, consulté le 21 septembre 2020. URL : http://journals.openedition.org/kernos/1848 ; DOI : https://doi.org/10.4000/kernos.1848 
pensée par images. Il faut donc considérer le jeu des images pour lui-même... on en sera plus sûrement récompensé qu'à faire la chasse aux 'usages primitifs', maigre butin épars'»(p. 202). C'est donc le travail de la légende sur les représentations et les pratiques d'une société qu'il analyse, dans un cheminement d'une étonnante modernité. L'ouvrage se referme sur un inventaire des archives, une bibliographie et un index des noms antiques.

Vinciane Pirenne-Delforge (FNRS - Université de Liège)

\section{Actes de colloques, ouvrages collectifs et mélanges}

AcCorinti Domenico, Chuvin Pierre (éds), Des Géants à Dionysos. Mélanges de mythologie et de poésie grecque offerts à Francis Vian, Alessandria, Ed. dell'Orso, 2003 (Hellenica. Testi e strumenti di letteratura greca antica, medievale e umanistica, 10).

D. ACCORINTI, Parturiunt montes an parturiuntur? La nascita delle montagne nel mito, p. 124; A. Bernabé, Autour du mythe orphique sur Dionysos et les Titans. Quelques notes critiques, p. 25-39; A. CAMERON, A Greek source of Ovid's Metamorphoses?, p. 41-59; J. YOYOTTE, P. CHUVIN, Autour du solstice d'hiver: Épiphane et les fêtes alexandrines de l'éternité, p. 135-145; W. FAUTH, Kosmische Katastrophen im griechischen Mythos, p. 61-73; Ch. PIETSCH, Einheit oder bunte Fülle? Zu Funktion und Integration des Mythos in den Epinikien des Bakchylides am Beispiel des Herakles-Meleager-Mythos in B. 5, p. 173-188; A. KÖHNKEN, Apoll-Aitien bei Kallimachos und Apollonios, p. 207-213; P. CHuvin, Anaphé, ou la dernière épreuve des Argonautes, p. 215-221; S. SAÏD, Divination et devins dans les Argonautiques, p. 255-275; J.L. LigHTFOOT, Giants and Titans in Oracula Sibyllina 1-2, p. 393-401; H. FrangOUlis, Les pierres magiques dans les Dionysiaques de Nonnos de Pannopolis, p. 433-445.

Alvar EzQuerra Antonio, González Castro José Francisco (éds.), Actas del XI Congreso Español de Estudios Clásicos (Santiago de Compostela, del 15 al 20 de septiembre de 2003), Madrid, 2005, vol. I.

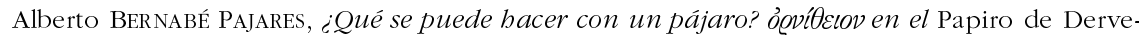
ni, p. 287-297; Francesc CASADESÚs BORDOY, Adaptaciones e interpretaciones estoicas de los poemas de Orfeo, p. 309-18; Ana Isabel JimÉNEZ SAN CRISTÓBAL, El concepto de dike en el orfismo, p. 351-361; Raquel MARTín HERnÁNDEZ, Orfeo, el orfismo y la magia en los s. Vy IV a. C., p. $375-$ 383; Inmaculada Rodríguez Moreno, Influencias de los Oráculos Caldeos en Porfirio de Tiro,

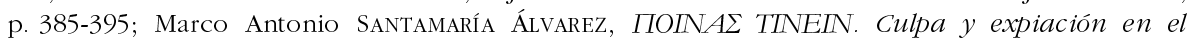
orfismo, p. 397-405; Pilar DÍEZ DEL CORRAL CORREDOIRA, Los contextos del amor. Eros en las imágenes de cortejo de Dioniso y Ariadna, p. 431-441; Fátima DíEz Platas, Agua para los vivos, agua para los muertos: sobre iconografía y función en los lutróforos áticos de época arcaica, p. 443-453; Jesús-María NiETO IBÁÑEZ, El mito de Tifón y el antijudaísmo de Egipto, p. 525-534; María Elena Rodríguez Ten, Las Dédalas de Platea: ¿un festival de Hera?, p. 569-577.

Ambos Claus, Hotz Stephan, Schwedier Gerald, Weinfurter Stefan (éds), Die Welt der Rituale. Von der Antike bis heute, Darmstadt, Wissenschaftliche Buchgesellschaft, 2005.

E. Stavrianopoulou, Die „gefahrvolle“ Bestattung von Gambreion, p. 24-37; ead., Priester gesucht, Erfahrung erwünscht!, p. 90-95; St. HOTZ, Delphi-ein störrische Ziege und Priester unter Druck, p. 102-105; A. CHANIOTIS, Ein mißverstandenes Ritual der griechischen Diplomatie: Geschichte als Argument, p. 106-109; St. HOTZ, Eine „grenzüberschreitende“ Prozession in Athen, p. 133-136; E. Stavrianopoulou, Göttin Bendis in Attika, p. 144-155; A. Chaniotis, Akzeptanz 
von Herrschaft durch ritualisierte Dankbarkeit und Erinnerung, p. 188-204; E. STAVRIANOPOULOU, Die Würde des Priesters ist unantastbar, p. 225-232

Angeli Bernardini Paola (éd.), La città di Argo. Mito, storia, tradizioni poetiche. Atti del convegno internazionale (Urbino, 13-15 giugno 2002), Roma, Ateneo, 2004.

M. Piérart, Deux voisins. Argos et Épidaure (mythe, société, histoire), p. 19-34; C. BrillanTe, Genealogie argive: dall'asty phoronikon alla città di Perseus, p. 35-56; E. Cingano, Tradizioni epiche intorno ad Argo da Omero al VI sec. a.C., p. 59-78; O. OLIVIERI, Analoge rovesciamenti tra $i$ Sette e gli Epigoni, p. 79-91; M. CANNATA FERA, Poesia e statuaria: gli eroi argivi di Pindaro e di Antifane, p. 95-106; B. D’Alessio, Argo e l'Argolide nei canti cultuali di Pindaro, p. 107-125; P. ANgel Bernardini, La città e i suoi miti nella lirica corale: l'Argolide e Bacchilide, p. 127-145; G. Avezzù, Mappe di Argo, nella tragedia, p. 149-161; C. CATENACCI, Realtà e immaginario negli scudi dei Sette contro Tebe di Eschilo, p. 163-176; C. CALAME, Le funzioni di un racconto genealogico: Acusilao di Argo e la nascita della storiografia, p. 229-243; E. SuÁreZ DE LA TORRE, Los oráculos sobre Argos, p. 245-262; M. DORATI, Pausania, le Pretidi e la triarchia argiva, p. 295-320.

Bakewell Geoffrey W., Sickinger James P. (éds), Gestures. Essays in ancient history, literature, and philosophy presented to Alan L. Boegehold on the occasion of his retirement and his seventy-fifth birthday, Oxford, Oxbow books, 2003.

L. ATHANASSAKI, A divine audience for the celebration of Asopichus'victory in Pindar's Fourteenth Olympian ode, p. 3-15; P. GREEN, Delivering the go(o)ds: Demetrios Poliorcetes and Hellenistic divine kingship, p. 258-277; D.D. PHILlips, The bones of Orestes, p. 301-316.

Binder Gerhard, EFFE Bernd, GLei Reinhold (éds), Gottmenschen. Konzepte existenzieller Grenzüberschreitung im Altertum, Trier, Wissenschaftlicher Verlag Trier, 2003 (Bochumer Altertumswissenschaftliches Colloquium, 55).

L.-M. GÜNTHER, Hellenistische Könige als Götter: Das Beispiel der Ptolemäer, p. 9-26; B. EFFE, Der Held als Gott: Die Apotheose des Herakles in der alexandrinischen Dichtung, p. 27-43; Th. PAUlSEN, Verherrlichung und Verspottung. Die Gestalt des 'Gottmenschen' bei Philostrat und Lukian, p. 97-120; W. GEERLINGS, Die theios anêr-Vorstellung der 'Religionsgeschichtlichen Schule' und ibre Kritik, p. 121-131.

Broze Michèle, Couloubaritsis Lambros, Hypsilanti Aimilia, Mavromoustakos Platon, Viviers Didier (éds), Le mythe d'Hélène, Bruxelles, Éditions Ousia, 2004 (coll. « Mythes et religions »).

Philippe Rousseau, La Toile d'Hélène (Iliade III, 125-128), p. 9-43; Ioanna PapadopoulouBelmehdi, Ethos et Epos: Hélène dans la Rhapsodie psi de l'Odyssée, p. 45-88; Pietro PuccI, Prosopopée d'Hélène, p. 89-119; Lambros Couloubaritsis, Les passions d' "Hélène », p. 121-131; Michèle Broze, Françoise LABrique, Hélène, le cheval de bois et la peau de l'âne, p. 133-187; Michalis MeraKuIs, Références folkloriques au sujet de la belle Hélène, p. 189-195; Costas GIORgoussopoulos, L'Hélène de Faust II : une critique du romantisme?, p. 197-202; Mairi ECONOMOU, Helen and her Lovers, p. 203-219; André DeISSER, Hélène dans la littérature néohellénique, p. 221-242; V. KONDOYANNI, De la guerre de Troie à la question chypriote: Hélène dans l'œuvre de Séféris, p. 243-252; G. Giatromanolakis, Giannis Ritsos: Hélène. Un poème politique?, p. 253-268; Jina KALOGIROU, Le crépuscule des héros : mythe et ethos dans la quatrième dimension de Yannis Ritsos, p. 269-284; Platon MaVRomoustakos, Hélène dans le théâtre grec moderne, p. 285-293.

Candau Morón José María, González Ponce Javier, Cruz Andreotti Gonzalo (éds), Historia y mito. El pasado legendario como fuente de autoridad. Actas del Simposio Internacional celebrado en Sevolla, Valverde del Camino y Huelva (abril 2003), Málaga, Servicio de Publicaciones, Centro de ediciones de la Diputación, 2004. 
Ph. A. STADTER, From the mythical to the bistorical paradigm: the transformation of myth in Herodotus, p. 31-46; E. LANZILlOTA, Patriotismo e tradizioni mitiche. Le origine della storiografia locale in Grecia, p. 47-55; G. SCHEPENS, J. BOLLANSÉE, Myths on the origins of peoples and the birth of universal bistory, p. 57-75; A. PÉREZ JIMÉNEZ, Dos héroes fundadores. La Vidas de Teseo y Rómulo de Plutarco, p. 165-178; P. GIOVANNELLI-JOUANNA, L’hellénisme chez les historiens grecs et le Périple d'Héraclès dans l'ouest de la Méditerranée. Les enjeux du mythe, p. 193-208.

CAPDEville Gérard (éd.), L'Eau et le feu dans les religions antiques. Actes du premier colloque international d'histoire des religions organisé par l'École doctorale Les Mondes de l'Antiquité, Paris, 18-20 mai 1995, Université de Paris IV-Sorbonne / École Normale Supérieure, Paris, De Boccard, 2004 (De l'Archéologie à l'Histoire).

Dominique Briquel, Le thème indo-européen du feu dans l'eau. Application à la Grèce, p. 1123; Alain MOREAU, L'eau sur le feu, le feu dans l'eau. La marmite de Médée, l'épée de Clytemnestre et l'ordre cosmique, p. 25-35; Gérard CAPDEVILLE, Le volcan dans la mer ou l'initation d'Hèphaistos, p. 37-59; Paul WATHELET, Le combat d'Héphaïstos contre le Scamandre et le Simoïs dans l'Tliade, p. 61-77; Françoise BADER, L'eau et le feu du guerrier: l'ordalie d'Achille dans le Scamandre-Xanthe, p. 79-115; Pierre SOMVILLE, Virgile et la source grecque. Le rôle des quatre éléments dans le sixième livre de l'Énéide, p. 149-154.

Couloubaritsis Lambros, Ost J.-F. (éds), Antigone et la résistance civile, Bruxelles, Éditions Ousia, 2004.

Jacques TAminiaux, Antigone dans l'bistoire de la philosophie, p. 9-39; Ana IRIARTE, Antigone Autonomos, p. 41-55; Pierre Somvile, Antigone et l'autre lumière, p. 57-62; Sophie Kuimis, Antigone et Créon à la lumière du «terrifiant/extraordinaire » (deinotès) de l'bumanité grecque, p. 63-102; Jean Alaux, Antigone et Niobé: sous le signe de l'oxymore, p. 103-125; Mariela Rotaru CONSTANTINESCu, Pour une phénoménologie du poétique dans la tragédie "Antigone » de Sophocle et ses avatars littéraires, p. 127-141; Myriam WATTHÉE-DELMOTTE, "Antigone ne se retourne pas 》. Écriture et résistance chez Henri Bauchau, p. 143-159; Benô̂t FRYDMAN, La rbétorique judiciaire dans l'Antigone de Sophocle, p. 161-183; Philippe GÉRARD, Les enjeux politiques d'Antigone, p. 185-203; Anne-Marie Roviello, Antigone n'est pas toujours là où on l'attend, p. 205-230; JeanYves CARLIER, Le cri d'Antigone, de l'exil à la résistance, p. 231-244; Monique LAMBERT, Antigone et le civisme aujourd'bui, p. 245-270; Entretien avec Henry Bauchau, p. 271-276.

Csapo Eric, Miller Margaret C. (éds), Poetry, Theory, Praxis. The social life of myth, word and image in ancient Greece. Essays in bonour of William J. Slater, Oxford, Oxbow books, 2003.

R. FOWLer, Pelasgians, p. 2-18; M.C. Miller, Art, myth and reality: Xenophantos' lekythos reexamined, p. 19-47; R. HAMILTON, Lenaea vases in context, p. 48-68; E. CSAPO, The dolphins of Dionysus, p. 69-98; B. SEIDENSTICKER, The chorus of the satyr-play, p. 100-121; E. SIMON, Hypermestra and Lynkeus, p. 122-128; M. CROPP, Hypsipyle and Athens, p. 129-145; J.R. PORTER, Orestes the ephebe, p. 146-178; J.R. GREEN, Speculations on the tragic poet Sthenelus and a comic vase in Richmond, p. 179-185; R. GARLAND, Up-staging Greek tragedy: the use (and abuse) of genre?, p. 186-202; M. STEINHART, Literate and wealthy women in Archaic Greece: the case of Telestas Hydria, p. 204-231; M.W. DICKIE, The topic of envy and emulation in an agonistic inscription from Oenoanda, p. 232-246; N. ROBERTSON, Aesop's encounter with Isis and the Muses, and the origins of the Life of Aesop, p. 247-266.

DASEN Véronique (éd.), Naissance et petite enfance dans l'Antiquité. Actes du colloque de Fribourg, 28 novembre - $1^{\text {er }}$ décembre 2001, Fribourg/Göttingen, Academic Press / Vandenhoeck \& Ruprecht, 2004 (Orbis Biblicus et Orientalis, 203).

Vincent BARRAS, La naissance et ses recettes en médecine antique, p. 93-102; John BOARDMAN, Unnatural conception and birth in Greek mythology, p. 103-112; Philippe BORGEAUD, L'enfance au miel dans les récits antiques, p. 113-126; Véronique DASEN, Femmes à tiroir, p. 127-144; Mark 
GOLDEN, Mortality, mourning and mothers, p. 145-157; Yvette MORIZOT, Offrandes à Artémis pour une naissance. Autour du relief d'Archinos, p. 159-170; Vinciane PIRENNE-DELFORGE, Qui est la Kourotrophos athénienne?, p. 171-185.

Guglielmo Marcella, Bona Edoardo (éds), Forme di comunicazione nel mondo antico e metamorfosi del mito. Dal teatro al romanzo, Allessandria, Ed. dell'Orso, 2003 (Culture antiche, studi e testi, 17).

A. AlOni, Teseo, un eroe dalle molte identità, p. 1-22; A. BELTRAMETTI, Storie e drammi di regalità nell'Atene periclea. Di Ciro e di Edipo, di Solone e del Sileno, p. 23-41; J. PòrTUlas, 'Molto hai toccato il moi cuore, figlio di Filammone... (Reso, 890-973), p. 43-48; P. PINOTTI, Metamorfosi del mito e prefigurazioni del romanzo nella scrittura platonica, p. 49-78; J.-M. BERTRAND, Mensonges, mythes et pratiques du pouvoir dans les cités platoniciennes, p. 79-96; C. CHIESA, Platon et le bon usage des fables platoniciennes, p. 97-111; A. JAULIN, La transformation du mythos dans la Poétique d'Aristote, p. 113-120; D. Micalella, I miti e l'arte del poeta tragico (Aristot. Poet. $1454 a 9$ ss.), p. 121-133; O. GENGLER, Héritage épique et lyrique dans la poésie alexandrine: les Dioscures et les Apharétides d'Homère à Lycophron, p. 135-147; F. BEssone, Discussione del mito e polifonia narrativa nelle Heroides, Enone, Paride ed Elena (Ov. Her. 5 e 16-17), p. 149-185; D. VAN MAL-MAEDER, Credibiles fabulas fecimus. Mythe, rhétorique et fiction dans les déclamations latines, p. 187-200; E. BERARDI, Mito e storia nella diatriba cinico-stoica (una lettura dell'or. 17 di Dione di Prusa), p. 201-213; C. HERRENSCHMIDT, Callirboé et Chariclée héroïnes monétaires? Une proposition à paropos de Chéréas et Callirboé de Chariton et des Éthiopiques d'Héliodore, p. $215-$ 233; D. CRISMANI, La donna velata e altri ricordi di scena tra le pagine del romanzo greco, p. 235241; G.F. GIANOTTI, Andromeda e Psiche. Storie nuziali e assunzioni in cielo, p. 243-257; M. CuRNis, Un tópos quasi immancabile: la tempesta marina tra teatro e romanzo, p. 259-273; R. FALCETTO, Il mito di Palamede nell'Heroikos di Filostrato, p. 275-297; M.T. Clavo, Comunicare a Delfi: lo Ione euripideo e le Etiopiche di Eliodoro, p. 299-321; M. SEITA, Oreste e Elettra al tempo di Robespierre. Nota a Les dieux ont soif di Anatole France, p. 323-334.

Karageorghis Vassos, Taifacos Ioannis (éds), The World of Herodotus. Proceedings of an intern. conference held at the Foundation A.G. Leventis, Nicosia, September 18-21, 2004, Nicosa, Foundation A.G. Leventis, 2004.

R. PARKER, Sacrificing twice seven children: queen Amestris' exchange with the god under the earth (7, 114), p. 151-157; P. FunKe, Herodotus and the major sanctuaries of the Greek world, p. 159-167; Th. HARRISON, Truth and lies in Herodotus' Histories, p. 255-263; D. HARVEY, Herodotus mythistoricus: Arion and the liar?, p. 287-305.

KOESTER Helmut (éd.), Ephesos. Metropolis of Asia. An interdisciplinary approach to its archaeology, religion, and culture, Cambridge, Mass., Harvard UP, 2004 (HThS, 42).

Ch. Thomas, At bome in the city of Artemis: religion in Ephesos in the literary imagination of the Roman Period, p. 81-117; D. KNIBBE, Via sacra Ephesiaca. New aspects of the cult of Artemis Ephesia, p. 141-155; H. THÜR, The processional way in Ephesos as a place of cult and burial, p. 157-199; St. FRIESEN, The cult of the Roman emperors in Ephesos: temple wardens, city titles, and the interpretation of the Revelation of John, p. 229-250; M. AURENHAMMER, Sculptures of gods and heroes from Ephesos, p. 251-280; J. WALTERS, Egyptian religions in Ephesos, p. 281-290.

Kotjabopoulou Eleni, Hamilakis Yannis, Halstead Paul, Gamble Clive, Elefanti Paraskevi (éds), Zooarchaeology in Greece. Recent advances, London, The British School at Athens, 2003 (Studies, 9).

G. FORSTENPOINTNER, Promethean Legacy: investigations into the ritual procedure of 'Olympian' sacrifice, p. 203-213; I. CHENAL-VELARDE, J. STUDER, Archaeozoology in a ritual context: the case of a sacrificial altar in geometric Eretria, p. 215-220; Y. HAMILAKIS, The sacred geography of bunting: wild animals, social power and gender in early farming societies, p. 239-247. 
Martínez PinNa Jorge (ed.), Mito y ritual en el antiguo Occidente mediterráneo, Málaga, 2002.

Juan F. MARTOS MONTIEL, Sexo y ritual: la prostitución sagrada en la antigua Grecia, p. 7-38; Francisco SÁnchez Jiménez, Prodigios y política: Filócoro F 67 Jacoby, p. 39-53; Dominique BRIQUel, Rite étrusque et mythe grec: les funérailles de Patrocle dans l'Iliade et le rituel de divinisation des morts en Étrurie, p. 73-90.

M. Mazoyer, O. Casabonne (éds), Studia Anatolica et varia. Mélanges offerts au professeur René Lebrun II, Paris, L'Harmattan, 2000 (coll. Kubaba. série Antiquité, 6)

Sophie LalagüE-Dulac, Typhon, doublet cilicien d'Héphaïstos?, p. 13-28; André MotTe, Xénophane de Colophon et la naissance d'une théologie nouvelle, p. 151-194; Isabelle TASsIGNON, Dionysos et les rituels dendrophoriques de Magnésie du Méandre, p. 315-335.

Mythe et mythologie dans l'Antiquité gréco-romaine, publié dans Europe. Revue mensuelle 82 année, 904-905 (août-septembre 2004).

Bernard MEZZADRI, Le mythe, objet tabou?, p. 3-8; Claude CALAME, Du muthos des anciens Grecs au mythe des anthropologues, p. 9-37; Diego LANZA, Nés de la même mère?, p. 38-54; Lucien Scubla, Sur le mythe de Prométhée et l'analyse du sacrifice grec, p. 55-72; Françoise LÉTOUBLON, Le rossignol, l'hirondelle et l'araignée, p. 73-102; Ezio PELLIzER, Épreuves d'amour, épreuves de mort, p. 103-118; Luc BRIsson, L'attitude de Platon à l'égard du mythe, p. 119-132; Bernard MEZZADRI, Socrate, le monstre et le père, p. 133-153; Jesper SVENBRO, Le mythe d'Ajax, p. 154-175; John SCHEID \& Jesper SVENBRO, Le mythe de Vertumne, p. 176-190; Mary BEARD, Sur la piste du mythe romain, p. 191-218; Florence DuPONT, Mythe et rituel à Rome, p. 219-230; Pierre et André SAUzEAU, La quatrième fonction, p. 231-253; David BOuviER, Le héros grec au pays des dictionnaires, p. 254-266; Alain MONNIER, Miroir du mythe-L'Inca Pachacuti, p. 267-275.

SCOlnicov Samuel, Brisson Luc (éds), Plato's Laws: From Theory into Practice. Proceedings of the $\mathrm{VI}^{\text {th }}$ Symposium Platonicum. Selected Papers, Sankt Augustin, Academia Verlag, 2003 (International Plato Studies, 15).

M. Schofield, Religion and philosophy in the Laws, p. 1-13; J. Dillon, Philip of Opus and the theology of Plato's Laws, p. 304-311; F. BRENK, Finding one's place: Eschatology in Plato's Laws and first-century Platonism, p. 312-319.

\section{Contributions particulières}

ALONI A., "L'ira di Era: tracce di committenza samia nell'Inno omerico a Apollo », in E. CAVALLINI (éd.), Samo. Storia, letteratura, scienza. Atti delle giornate di studio, Ravenna, 14-16 novembre 2002, Pisa/Roma, Istituti editoriali e poligrafici internazionali, 2004 (AION(fil). Quaderni 8), p. $13-29$.

ANDO Clifford, "A Religion for the Empire », in A.J. BOYLE, W.J. DOMInIK (éds), Flavian Rome. Culture, image, text, Leiden, Brill, 2003, p. 323-344.

ANEZIRI S., DAmASKos D., «Städtische Kulte im hellenistischen Gymnasion », in D. KAH, P. SCHOLZ (éds), Das bellenistische Gymnasion, Berlin, Akademie Verlag, 2004, p. 247-271.

ATHANASSIADi P., «Hellenism: a Theological Koine », in V. KARAgEORGHIs (éd.), The Greeks beyond the Aegean: from Marseilles to Bactria. Papers presented at an intern. symposium held at the Onassis cultural center, New York, $12^{\text {th }}$ october 2002, New York, 2003, p. 189-207.

Aubriot Danièle, «Entre Héphaïstos et Poséidon. Cataclysmes homériques », in E. Foulon (éd.), Connaissance et représentations des volcans dans l'antiquité. Actes du colloque de ClermontFerrand, Université Blaise Pascal, 19-20 septembre 2002, Clermont-Ferrand, Presses Univ., 2004, p. $13-37$.

BERNABÉ A., "Hittites and Greeks. Mythical influences and methodological considerations », in R. Rollinger, C. Ulf (éds), Griechische Archaik. Interne Entwicklungen - Externe Impulse, Berlin, Akademie Verlag, 2004, p. 291-310. 
BÖHME Stephanie, "The 'naked goddess' in early Greek art: an orientalizing theme par excellence ", in N.C. STAMPOLIDIS, V. KARAGEORGHIS (éds), Ploes... See routes... Interconnections in the Mediterranean $16^{t h}-6^{t h}$ c. BC. Proceedings of the inter. symposium held at Rethymnon, Crete, September 2002, Athens, Univ. of Crete; A.G. Leventis Foundation, 2003, p. 363-370.

BoOKidis Nancy, "The sanctuaries of Corinth », in Ch. K. WiLliams II, N. BoOKIDIS (éds), Corinth. Results of excavations conducted by the American classical studies at Athens XX: Corinth, the centenary 1896-1996, Oxford, Oxbow books, The American school of classical studies at Athens, 2003, p. 247-259.

BREMMER Jan, «Pandora of the creation of a Greek Eve », in G.P. LuTTIKHUIzEN (éd.), The Creation of Man and Woman. Interpretations of the Biblical Narratives in Jewish and Christian Traditions, Leiden, Brill, 2000, p. 19-33.

Bremmer Jan, «Remember the Titans! », in C. Auffarth, L. STUckenbruck (éds), The Fall of the Angels, Leiden, Brill, 2003, p. 35-61.

BREMmER Jan, «Don't Look Back: From the Wife of Lot to Orpheus and Eurydice », in Ed NoORT, E. TigchelaAR (éds), Sodom's Sin. Genesis 18-19 and its Interpretations, Leiden, Brill, 2004, p. $131-145$.

CARITÀ Cristina, «Un episodio di asylia all'Heraion della Perachora », in G.D. ROCCHI, M. CAVALLI (éds), Il Peloponneso di Senofonte. Giornate di Studio del Dottorato di Ricerca in Filologia, Letteratura e Tradizione classica, Milano, 1-2 aprile 2003, Milano, Cisalpino, 2004, p. 93-113.

CASADIO Giovanni, "Hera a Samo», in E. CAVAllini (éd.), Samo. Storia, letteratura, scienza. Atti delle giornate di studio, Ravenna, 14-16 novembre 2002, Pisa/Roma, Istituti editoriali e poligrafici internazionali, 2004 ( $A I O N(f i l)$. Quaderni 8), p. 135-155.

CHANIOTIS Angelos, "Under the watchful eyes of the gods: divine justice in Hellenistic and Roman Asia Minor", in S. Colvin (éd.), The Greco-Roman East. Justice, Culture, Society, Cambridge UP, 2004 (Yale Classical Studies, 31), p. 1-43

Dally O., "'Pflege' und Umnutzung heidnischer Tempel in der Spätantike », in G. Brands, H.G. SEVERIN (éds), Die spätantike Stadt und ibre Christianisierung. Symposium vom 14. bis 16. Februar 2000 in Halle/Saale, Wiesbaden, Reichert, 2003, p. 97-114.

DeAcy S., Villing A., "Athena blues? Color and divinity in Ancient Greece », in L. CerChIAI, L. Janneu, F. Longo (éds), The Greek Cities of Magna Grecia and Siciy, Los Angeles, The Paul Getty Museum, 2004, p. 85-90.

Di DONATO Ricardo, « Il culto degli eroi ad Atene: l'evidenza e i modelli », in St. BRuni, T. CARUsO, M. MAssa (éds), Archaeologica pisana. Scritti per Orlanda Pancrazzi, Pisa, Giardini editori e stampatori, 2004 (Terra Italia. Collana di studi archeologici sull'Italia antica, 7), p. 143-146.

Dignas Beate, "Posidippus and the mysteries. Epitymbia read by the ancient historian ", in B. Acosta-Hughes, E. Kosmetatou, M. Baumbach (éds), Labored in Papyrus Leaves: perspectives on a epigram collection attributed to Posidippus (P.Mil.Vogl. VIII 309), Washington, Center for Hellenic Studies, 2004 (Hellenic Studies, 2), p. 177-186.

Dixsaut M., «Divination et prophétie (Timée 71a-72d)», in C. NATAli, S. Maso (éds), Plato physicus. Cosmologia e antropologia nel Timeo, Amsterdam, Hakkert, 2003, p. 275-291.

Felten F., "Neues zu Apollon und Demeter in Aigina », in B. Asamer, W. Wohlmayr (éds), Akten des 9. Österreichischen Archäologentages am Institut für Klassische Archäologie der Paris Lodron - Universität Salzburg, 6.-8. Dezember 2001, Wien, Phoibos Verlag, 2003, p. 41-45.

GiacometTI D., "Erodoto: la festa fra storia e rito», in A.-M. BIRASCHI, P. Desideri, S. RodA, G. ZECCHINI (éds), L'uso dei documenti nella storiografia antica, Perugia, Edizioni scientifiche italiane, 2004 (Incontri perugini di storia della storiografia, 12), p. 187-204.

Greco G. et al., "L'incidenza della ceramica attica nei santuari. Il caso di Gela », in R. PANVINI, F. GIUDICE (éds), Ta Attika. Veder greco a Gela. Ceramiche attiche figurate dall'antica colonia. Gela, Siracusa, Rodi, Roma, L' 'Erma' di Brestschneider, 2003, p. 157-184 (cf. supra, p. 521).

GUÉPIN J.-P., «Is there a night side to Greek religion? In defence of festivity », in M. ZIMMERMANN, R. VAN DER PAARDT (éds), Metamorphic reflections. Essays presented to Ben Hijmans at his $75^{t h}$ birthday, Leuven, Peeters, 2004, p. 41-67. 
HABICHT Christian, "Notes on the Priests of Athena Lindia », in B. VIRGILIO (éd.), Studi Ellenistici XVI, Pisa, Giardini Editori, 2005, p. 71-78.

Hauben Hans, "Christ versus Apollo in Early Byzantine Kourion? with a note on the so-called 'Panayia Aphroditessa' in Paphos », in B. JAnssens, B. RoOsen, P. VAn Deun (éds), Philomathestatos. Études de patristique grecque et textes byzantins offert à J. Noret à l'occasion de ses 65 ans, Leuven, Peeters, 2004 (Orientalia Lovaniensia Analecta, 137), p. 269-284.

HENRICHS Albert, «Writing Religion. Inscribed Texts, Ritual Authority, and the Religious Discourse of the Polis ", in H. Yunis (éd.), Written Texts and the Rise of Literate Culture in Ancient Greece, Cambridge, Univ. Press, 2003, p. 38-58.

Hidal St., "When and why is a sacrifice rejected? A comparison between Homer and the Old Testament », in P. SANDIN, M. WIFSTRAND SchIEBE (éds), Dais Philêsistephanos. Studies in bonour of Professor Staffan Fogelmark. Presented on the occasion of his $65^{\text {th }}$ birthday, Uppsala, Dahlia books, 2004, p. 11-18.

HOwIE G., "Apollo's dealings with Chiron and Croesus: ambiguity and hymnic predication in Hesiod's Theogony, Pindar's $9^{\text {th }}$ Pythian and Herodotus I ", in P. SANDIN, M. WifSTRAND SCHIEBE (éds), Dais Philêsistephanos. Studies in honour of Professor Staffan Fogelmark. Presented on the occasion of his $65^{\text {th }}$ birthday, Uppsala, Dahlia books, 2004, p. 21-69.

JAMESON Michael, «Mapping Greek Cults», in F. KolB (éd.), Chora und Polis, München, Oldenbourg, 2004 (Schriften des Historischen Kollegs. Koloquien, 54), p. 147-183.

JOUAN François, "Dieux et héros d'Athènes dans l'Érechthée d'Euripide ", in IX Congrès intern. de Delphes sur le drame grec ancien (Delphes, juillet 1998), Athènes, 2004, p. 57-69.

KARAGEORGHIS Jacqueline, "The goddess of Cyprus between the Orient and the Occident ", in N.C. StAmpolidis, V. KARAgEORghis (éds), Ploes... See routes... Interconnections in the Mediterranean $16^{t b}-6^{t b}$ c. BC. Proceedings of the inter. symposium held at Rethymnon, Crete, September 2002, Athens, Univ. of Crete; A.G. Leventis Foundation, 2003, p. 353-362.

KEARns Emily, "The Gods in the Homeric Epics », in R. FOwLER (éd.), The Cambridge Companion to Homer, Cambridge UP, 2004, p. 59-73.

Kralli I., "The date and context of divine honours for Antigonos Gonatas - a suggestion ", in O. Palagia, S.V. Tracy (éds), The Macedonians in Athens 322-229 B.C. Proceedings of an intern. conference held at the University of Athens, May 24-26, 2001, Oxford, Oxbow books, 2003, p. 61-66

MARI M., " Macedonians and anti-Macedonians in early Hellenistic Athens: reflections on asebeia, in O. Palagia, S.V. Tracy (éds), The Macedonians in Athens 322-229 B.C. Proceedings of an intern. conference held at the University of Athens, May 24-26, 2001, Oxford, Oxbow books, 2003, p. 82-92

MOREAU Alain, «Une pratique des magiciennes et sorcières de l'Antiquité : les perturbations astrales et météorologiques ", in Chr. CussET (éd.), La météorologie dans l'Antiquité entre science et croyance, Université de St-Étienne, 2003, p. 169-178.

MOREAu Alain, "Tithonos », in B. BAKHOUche (éd.), L'Ancienneté chez les Anciens. II : La vieillesse dans les sociétés antiques : la Grèce et Rome, Univ. de Montpellier III, 2003, p. 341-356.

MOTTE André, «Nativité divine à l'ombre du palmier de Délos et naissance d'un philosophe sous un platane de la campagne athénienne ", in M. MAZOYER, J. PÉrEz REY, R. LEBrun, F. MALBRANLABAT (éds), L'arbre: symbole et réalité. Actes des Premières journées universitaires de Hérisson organisées par la ville de Hérisson et les Cahiers KuBABA (Université de Paris I - PanthéonSorbonne) les 21 et 22 juin 2002, Paris, L'Harmattan, 2003 (Collection KUBABA), p. 159-174.

MOTTE André, "Figures du prêtre dans la littérature grecque », in A. MOTTE, P. MARChETTi (éds), La figure du prêtre dans les grandes traditions religieuses. Actes du Colloque en hommage à M. l'abbé Julien Ries à l'occasion de ses 80 ans par les Départements de Langues et littératures classiques et de Philosophie des Facultés Universitaires Notre-Dame de la Paix en collaboration avec la Société belgo-luxembourgeoise d'Histoires des Religions (Namur, du 26 au 28 octobre 2000), Leuven, Peeters, 2005 (Collection d'Études classiques, 20), p. 1-31. 
MOTTE André, "Tempo della festa e tempo del mito nella religione greca », in N. SPINETO (éd.), Interrompere il quotidiano. La costruzione del tempo nell'esperienza religiosa, Milano, Jaca Book, 2005, p. 61-82.

OBBINK Dirk, «Vergil's De pietate: from Ehoiae to allegory in Vergil, Philodemus and Ovid », in D. Armstrong, J. Fisch, P. Johnston, M.B. Skinner (éds), Vergil, Philodemus, and the Augustans, Austin, Texas UP, 2004, p. 175-209.

OTто B., «Opferbräuche im Demeterheiligtum von Herakleia in Lukanien », in B. ASAMER, W. WohlmaYr (éds), Akten des 9. Österreichischen Archäologentages am Institut für Klassische Archäologie der Paris Lodron - Universität Salzburg, 6.-8. Dezember 2001, Wien, Phoibos Verlag, 2003, p. 147-150.

PARKER Robert, "What are sacred laws?», in E.M. HARRIS, L. RUBINSTEIN (éds), The Law and the Courts in Ancient Greece, London, Duckworth, 2004, p. 57-70.

Pellizer Ezio, "Il mito e la città », in M. VeTTA (éd.), La civiltà dei Greci. Forme, luoghi, contesti, Roma, Carocci editore, 2001, p. 105-129.

ROwE Ch., "The status of 'myth' in Plato's Timaeus », in C. NATALI, S. Maso (éds), Plato physicus. Cosmologia e antropologia nel Timeo, Amsterdam, Hakkert, 2003, p. 21-31.

SHAPIRO Alan, "Theseus and Adriadne on Crete: the Dinos Painter's krater from Gela ", in R. PANvini, F. Giudice (éds), Ta Attika. Veder greco a Gela. Ceramiche attiche figurate dall'antica colonia. Gela, Siracusa, Rodi, Roma, L' 'Erma' di Brestschneider, 2003, p. 229-238.

Sineux Pierre, "La visite au sanctuaire : le Mime IV d'Hérondas ou propos sarcastiques sur une émotion esthétique », in C. BERTHO LAVENIR (éd.), La visite du monument, Clermont-Ferrand, Presses Universitaires Blaise-Pascal, 2004 (Collection Histoires croisées), p. 31-48.

STRATIKI Kerasia, «Melas in Greek cultural practices: the case of heroic sacrifices in the Periegesis of Pausanias ", in L. CerchiaI, L. JAnneli, F. LONGO (éds), The Greek Cities of Magna Grecia and Siciy, Los Angeles, The Paul Getty Museum, 2004, p. 106-109.

SuÁREZ DE LA TORRE Emilio, "L'eau dans la religion et la magie en Grèce ancienne », in M.Fr. MARIEn, P. VoIsin (éds), Actes du XXXVI Congrès de l'Association des professeurs de langues anciennes de l'enseignement supérieur, Pau 23, 24 et 25 mai 2003, Pau, 2004, p. 77-99.

Turcan Robert, "Note sur les 'dieux portables'», in Fr. Chausson, Ét. WolfF (éds), Consuetudinis amor. Fragments d'bistoire romaine (II - Vi siècles) offerts à Jean-Pierre Callu, Roma, 'L'Erma' di Bretschneider, s.d. (Saggi di Storia Antica, 19), p. 409-417.

VAN BREMEN Riet, "Leon son of Chrysaor and the religious identity of Stratonikeia in Caria ", in S. Colvin (éd.), The Greco-Roman East. Justice, Culture, Society, Cambridge UP, 2004 (Yale Classical Studies, 31), p. 207-244.

Villani Stefano, "Presagi, prodigi e sacrifici nelle Elleniche, in G.D. Rocchi, M. Cavalli (éds), Il Peloponneso di Senofonte. Giornate di Studio del Dottorato di Ricerca in Filologia, Letteratura e Tradizione classica, Milano, 1-2 aprile 2003, Milano, Cisalpino, 2004, p. 287-305

WARD-PERKINS B., "Reconfiguring sacred space: from pagan shrines to Christian churches », in G. BRANDS, H.-G. SEVERIN (éds), Die spätantike Stadt und ihre Christianisierung. Symposium vom 14. bis 16. Februar 2000 in Halle/Saale, Wiesbaden, Reichert, 2003, p. 285-290.

Wigodsky M., "Emotions and immortality in Philodemus, On the gods 3 and the Aeneid ", in D. Armstrong, J. Fisch, P. Johnston, M.B. Skinner (éds), Vergil, Philodemus, and the Augustans, Austin, Texas UP, 2004, p. 211-228. 